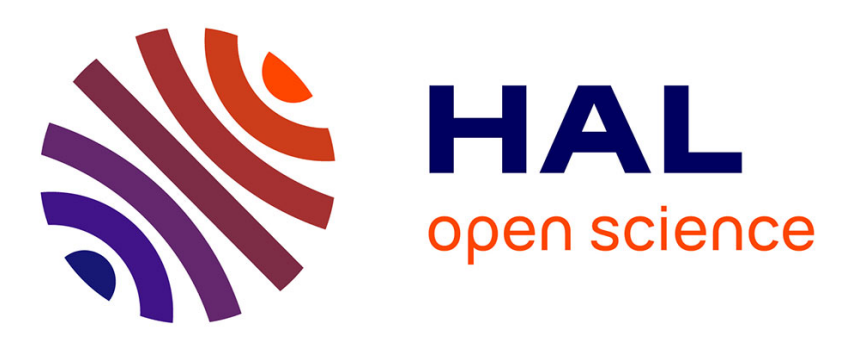

\title{
What Made the Tour Successful? Competitive Balance in the Tour de France, 1947-2017
}

Jean-François Mignot, Vladimir Bačik, Michal Klobučník

\section{To cite this version:}

Jean-François Mignot, Vladimir Bačik, Michal Klobučník. What Made the Tour Successful? Competitive Balance in the Tour de France, 1947-2017. Sport in Society, In press, 10.1080/17430437.2019.1621844 . halshs-02144696

\section{HAL Id: halshs-02144696 \\ https://shs.hal.science/halshs-02144696}

Submitted on 6 Jun 2019

HAL is a multi-disciplinary open access archive for the deposit and dissemination of scientific research documents, whether they are published or not. The documents may come from teaching and research institutions in France or abroad, or from public or private research centers.
L'archive ouverte pluridisciplinaire HAL, est destinée au dépôt et à la diffusion de documents scientifiques de niveau recherche, publiés ou non, émanant des établissements d'enseignement et de recherche français ou étrangers, des laboratoires publics ou privés. 


\title{
What Made the Tour Successful? \\ Competitive Balance in the Tour de France, 1947-2017
}

\author{
Jean-François Mignot, Vladimir Bačik, Michal Klobučník
}

\begin{abstract}
The Tour de France is the most popular and prestigious bicycle race in the world. Since the 1980s, it has also had increasing economic success. Is such economic success related to improvements in competitive balance among riders, i.e. the degree of parity among opponents and the resulting difficulty to predict the competition's end result? We compute several measures of static (annual) and dynamic (year-to-year) competitive balance for the yellow jersey from 1947 to 2017, both among the top five riders and among team leaders. Our main result is that competitive balance in the Tour de France has not improved much since 1947: the time performances of top riders and team leaders have not become closer to each other or harder to predict from one year to the next. Therefore, the increasing economic success of the Tour since the 1980s cannot be attributed to improvements in the race's competitive balance. Other factors must have been driving the increasing demand for the Tour, including better-quality television broadcasting of the event.
\end{abstract}

Keywords

Cycling; Tour de France; quantitative history; competitive balance; competitive intensity; sport performance 


\section{Introduction}

The Tour de France, which was created in 1903, is a three-week bicycle race held in July on the roads of France and neighboring countries. It is the most popular and prestigious bicycle race in the world. Since the 1980s it has also become the most profitable race for organizers, sponsors and riders, which is why it has been called a 'high-quality product' (Andreff, 2015) How did this race become so successful economically?

According to an influential economic theory, the demand for a sport show is partly explained by 'competitive balance', i.e. the degree of parity among opponents and the resulting difficulty to predict the competition's end result ('outcome uncertainty'). Competitive balance may be attractive on its own, but also because it tends to intensify riders' incentives and willingness to fight for victory ('competitive intensity'). Indeed, many Tour fans would agree that the highly contested 1964 Tour pitting French champions Jacques Anquetil against Raymond Poulidor and the 1989 Tour, which Greg LeMond won on the last stage by only eight seconds, were among the most unpredictable, competitive and legendary editions of the race (Chany and Cazeneuve 2003; McGann and McGann 2006). However, very little is known about competitive balance in the Tour de France. Is it high or low? Did it change in the long term and if so, how? And is the increasing economic success of the Tour since the 1980s related to improvements in competitive balance?

This article analyzes competitive balance in the Tour since 1947. As the history of the Tour reveals, competitive balance and competitive intensity have long been major concerns for the organizers. We compute several long-term measures of static (annual) and dynamic (year-to-year) competitive balance for the yellow jersey, both among the top five riders and among team leaders. Our main result is that the increasing economic success of the Tour since the 1980 s cannot be attributed to improvements in the race's competitive balance. A more likely explanation might be better-quality television broadcasting of the event.

\section{The Tour's Success and Competitive Balance}

\section{a. The Success of the Tour}

In the early twentieth century, bicycle races became one of the most popular shows in European countries such as Belgium, France and Italy (Gaboriau 2003; Mignot 2015a). The Tour de France was created in 1903 by a French sport newspaper, L'Auto, to report on the race and thereby increase its circulation and advertisement revenues (Dauncey and Hare 2003). The race was an immediate success and it rapidly became the most popular bicycle race in Europe. The Tour was run from 1903 to 1939 with varying rules and formats but as France became occupied by Nazi Germany, the race was not run from 1940 to 1946.

Since its new beginning in 1947, the Tour has remained relatively popular. The proportion of adults in France who claim they personally like the Tour de France went from $59 \%$ in 1964 to $44 \%$ in 2010 and then $49 \%$ in 2011-2014 (Ifop 2014). The Tour is also popular in some - not all - other European countries: in 2011, the share of adults who claim they personally like the Tour de France was close to $50 \%$ in France, Italy and Spain but lower in the UK (35\%) and still lower in Germany (28\%) (Ifop 2011).

It is only since the 1980 s, however, that this popular success transformed into a major economic success, with a very large increase in the Tour's revenues (Figure 1; Mignot 2016). While the Tour was often in deficit from the late 1930s to the 1970s, its revenues were multiplied by twenty between the early 1980s and late 2000s, largely because of the surge in both French and foreign television broadcasting rights (Van Reeth 2015). Nowadays, the Tour's annual revenues are between 150 and 170 million euros (Van Reeth 2015b).

Why is the Tour de France such a success? Watching the race on the roadside with one's family, close to the pain and drama of the race, was always free. Learning about the 
race in the newspapers, in cinema newsreels and on the radio enabled fans to follow their (national) heroes' physical performances. Watching the race on television also enables spectators to watch great landscapes (Mignot 2015a). Given that cycling is a strategically complex sport, Tour fans may be interested in who will win and also how (Mignot 2015b). However, the demand for a sporting event such as a bicycle race must somehow be related to competitive balance (how equal riders are) as well as the partly resulting competitive intensity (how much riders fight) (on the distinction between these concepts, see Scelles et al. 2013).

\section{b. Competitive Balance as an Element of Race Attractiveness}

Competitive balance contributes to the attractiveness of the Tour in two senses. First, it generates 'uncertainty of outcome' (Rottenberg 1956; Neale 1964) and spectators' feeling of suspense, which supposedly are at the origin of the demand for most if not all individual or team sport events (Szymanski 2006; Humphreys and Watanabe 2012; Leed and Allmen 2016). As Dejonghe pointed out about sport leagues, 'If the top club always beats the next ranked club, and so on, the games would be exhibitions, not contests, and they would have little market value' (Dejonghe 2015). Indeed, if spectators knew the Tour winner in advance or when and how he would turn out to win, few people would be interested. Actually, most professional riders usually respect and enforce certain informal norms which tend to improve competitive balance among contenders: 'riders wait for those who are taking bathroom or feeding breaks, do not attack when a competitor crashes, and maintain a non-competitive pace on the final day of the three-week long race. We maintain that the set of unofficial norms increases the attractiveness of the Tour de France for spectators and thus contributes to its profitability by discouraging the opportunistic behavior of individual cyclists' (Fink and Smith 2012).

Second, competitive balance may make the Tour attractive indirectly, by increasing competitive intensity. When riders are more equal (high competitive balance), this tends to incentivize them to fight harder and take more risks to win or to gain a better ranking (high competitive intensity). By contrast, when a rider or team clearly dominates the race, riders have no hope of winning and no reason to fight, except perhaps to maintain their ranking. This is why in 1952, when the campionissimo Fausto Coppi dominated the race as early as the $10^{\text {th }}$ stage, organizers doubled the second-place cash prize so that riders fight for second if not first place.

The influence of competitive balance on the demand for a sport show might be questionable in specific circumstances, e.g. when spectators are willing to trade competitive balance against a higher chance that their national team wins or that a world record is hit. Interestingly, however, the Tour de France is one of the few sport shows in which most teams are not based on nationality (at least since 1961, except in 1967 and 1968) and where there are relatively few records to beat. Therefore, one would expect that competitive balance is especially important in explaining the success of the Tour, including its increasing economic success since the 1980 s.

\section{c. Competitive Intensity as a Goal for Organizers}

As cyclists often collude to share prizes instead of fighting for victory (low competitive intensity), Tour organizers have repeatedly tried to improve competition among riders in order to attract more spectators and thus increase the Tour's revenues and profits. This is why they have decided to shorten the race to make it more attractive to attack and counter-attack. While the 1947 Tour was close to 5,000 km long, in the 2010s the Tour was closer to 3,500 $\mathrm{km}$, with pretty wide year-to-year variations (Figure 2a). As the Tour started being broadcast live on the radio (1930s) and on television (1970s) and television broadcast rights became the Tour's main source of revenues (1990s), organizers shortened the race in order to make stages 
more nervous, livelier and to attract more radio listeners and television viewers. In the same vein, organizers have included short, particularly intensive mountain stages since the 2010s, once again to increase competition. Meanwhile the number of days of the Tour remained roughly constant, between 20 and 25 days (Figure 2a), which means that since 1947 the mean distance per stage has kept decreasing. This shortening of the race contributed to improving riders' speed from $32 \mathrm{~km} / \mathrm{h}$ in the late 1940 s to $40 \mathrm{~km} / \mathrm{h}$ in the $2010 \mathrm{~s}$ (Figure 2c). Precisely, riders' speed strongly increased from 1947 to the early 1960s but also - although less rapidly - from the early 1970s to the mid-2000s (Figure 2c). Other factors involved in the long-term improvement of riders' speed are: better road quality; better equipment; riders' professionalization and better physical preparation including physical, physiological, nutritional and strategic determinants of performance (Atkinson and Davison 2003); and perhaps also doping (Vandeweghe 2015). As a result, the total duration of the Tour decreased from close to 150 hours in 1947 to fewer than 100 hours in the 2010s for both the winner and the mean finisher (Figure $2 b$ ).

Another evolution which may have improved competitive intensity in the Tour is the increase in the number of riders and teams in the 1980s. While in 1980 there were 130 riders from 13 teams, in 1990 there were 198 riders from 22 teams (Figure 2d). Some of the teams that appeared in the 1980s were amateur teams from the U.S. and Colombia. In the 1990s other teams came from Eastern Europe (Van Reeth 2015a). However, the increasing number of teams may also have deepened the disparities among them, which may actually have reduced competitive balance, if not competitive intensity.

Finally, competition among riders may have increased following the prize pool changes that occurred since the 1980s. Indeed, since the 1980s the organizers have had the resources to triple the total prize pool (Mignot 2016), which is expected to intensify competition. In addition, the share of the total prize pool that goes to the yellow jersey went from less than 5 $\%$ in 1980 to close to $25 \%$ today, which should give second-ranked riders more incentives to take risks to win. Similarly, Scelles et al. (2013) have shown that in the French football Ligue 1 in 2008-2011, attendance at matches depends less on competitive balance (the point difference between the two teams) than on competitive intensity (the home team's point difference with ranks with sporting stakes, e.g. qualification in European competitions and relegation in inferior divisions).

The rest of this article aims at answering the following question: may the increasing economic success of the Tour since the 1980s be explained by increasing competitive balance? As Andreff (2015) wrote, 'Nobody needs more than a few riders' names to predict with great certainty who the winner will be. Thus, explaining Tour de France success by outcome uncertainty and its usual metrics in terms of competitive balance must be checked carefully.'

\section{Data and Indicators of Competitive Balance in the Tour de France, 1947-2017}

\section{a. Statistical Data}

The company owning the Tour de France recently made some of the historical statistics of the race available (www.letour.fr/en/). We collected these data along with additional data from www.tourfacts.dk and we use them for analyzing competitive balance in the Tour de France, from the standpoint of quantitative sport history (Vamplew 2015). The collected data was organized in a database that is available in the form of a website www.tdfrance.eu (Bačík and Klobučník 2013). These data include information on all participants in each Tour from 1947 to 2017, including information on riders such as Lance Armstrong who were 
disqualified after the official results were published. For each Tour we have the following individual information: the name of each rider who started the race; the name of his team; whether he finished the race; and if so, his final time. Practically, the performance of an individual rider who finished the race is calculated as its delay behind the winner, in percentage of the winner's time.

\section{b. Measures of Competitive Balance in Cycling Stage Races}

In league sports, where each team plays one-on-one against each of the other teams, quantifying competitive balance may seem relatively easy. A match's competitive balance is measured by teams' probabilities of winning (the closer to 0.5 , the more competitive the match) and the championship's competitive balance is measured by some indicator of the dispersion of teams' probabilities of winning. Attendance at baseball games depends, among other things, on 'the dispersion of percentages of games won by the teams in the league' (Rottenberg 1956; Neale 1964). However, this indicator does not make sense for cycling stage races such as the Tour de France, mainly because winning the maximum number of stages does not amount to winning the whole race. Conversely, a rider may win the Tour without winning a single stage, as shown by Roger Walkowiak in 1956 and Alberto Contador in 2010 before he was disqualified for doping.

At the stage level, several indicators of competitive balance or related concepts have been suggested in the relevant literature. Larson and Maxcy (2014) measure outcome uncertainty at the stage level through the likelihood that the stage winner was part of a breakaway rather than part of the sprinting peloton. They find that in the three Grand Tours, the use of two-way radio technology by riders and team directors in 1992-2010 was associated with a higher, not a lower likelihood of breakaway success (especially in mountain stages), compared to the 1985-1991 period. However, the share of stages which are won by a breakaway rider rather than a peloton's sprinter is an indicator of the unpredictability of stages' scenarios, not an indicator of competitive balance among riders or teams. Cabaud et al. review the literature on competitive balance in cycling and they introduce an interesting measure of competitive balance at the stage level called intra-stage 'competitive intensity' (Cabaud et al. 2015). However, computing this sophisticated indicator requires within-stage data, which are not available in the long or even in the medium term (Scelles et al. 2017).

At the race level, the level in which we are interested, other indicators have been used. Mignot (2014) computes the number of times the yellow jersey switched from one rider to another (per racing day) and finds that this indicator shows no clear long-term evolution. However, this indicator is entirely based on the performances of the few riders who turned out to be the race leaders at least once in the race (Andreff 2015). This is why we suggest computing new, more robust measures of competitive balance in the Tour.

\section{c. Annual Indicators of Static and Dynamic Competitive Balance}

Building indicators of competitive balance in a cycling stage race requires making several choices, for which we rely on the innovative indicators proposed by Andreff (2015). First, as cycling has long been a professional sport and most riders have been riding for money, and as the highest cash prize has always been the yellow jersey, we choose to measure a rider's performance through his general classification time (in case he was among the finishers). We thus leave aside other - lower - cash prizes such as the king-of-the-mountains jersey (created in 1933) and the best sprinter's jersey (created in 1953), which today earn a rider 25,000 euros, i.e. only $5 \%$ of what the yellow jersey winner gets. In cycling, the general classification of the Tour is an indicator of the value of riders, which they use when negotiating contracts with the teams. 
Second, we choose to compute indicators of competitive balance not only among all riders, but also among the 'top five riders' (i.e., the best five finishers) and among 'team leaders' (i.e., each team's best finisher) (rows of Table 1). Indeed, although formally any participant may win the Tour, in reality only a tiny fraction of riders are able to compete for the yellow jersey, which is why we focus on competitive balance among the top five riders. In addition, because of labor division within teams (Candelon and Dupuy 2015), at most one rider per team usually competes for the yellow jersey (his teammates sacrifice their personal performances to help him win the yellow jersey), which is why we also address competitive balance among team leaders. Overall, these analyses should give us a complete picture of the evolution of competitive balance.

Third, we choose to compute indicators of both static and dynamic competitive balance (first columns of Table 1). While 'static' competitive balance is the degree of parity among opponents in a single edition of the race, 'dynamic' indicators measure to what extent the results of an edition of the Tour may have been predicted by the results of the previous edition. As is well known, several riders have been winning the Tour two or more years in a row: Jacques Anquetil, Eddy Merckx, Bernard Hinault, Miguel Indurain, Lance Armstrong, Christopher Froome, etc. What is needed is an indicator based on more than a tiny proportion of riders. A simple indicator of static competitive balance is the share of riders who finished the race. The corresponding indicator of dynamic competitive balance is the share of finishers in year $\mathrm{n}$ who had already finished the race in year $\mathrm{n}-1$ (given that they had started). As indicated, we also choose to measure competitive balance regarding race completion as well as final time (additional columns of Table 1).

Table 1. Indicators of Competitive Balance in the Tour de France

\begin{tabular}{|c|c|c|c|c|}
\hline & \multicolumn{2}{|c|}{ Static competitive balance } & \multicolumn{2}{|c|}{ Dynamic competitive balance } \\
\hline & $\begin{array}{l}\text { Regarding race } \\
\text { completion }\end{array}$ & $\begin{array}{c}\text { Regarding final } \\
\text { time }\end{array}$ & $\begin{array}{l}\text { Regarding race } \\
\text { completion }\end{array}$ & $\begin{array}{c}\text { Regarding final } \\
\text { time }\end{array}$ \\
\hline $\begin{array}{c}\text { Among } \\
\text { all } \\
\text { riders }\end{array}$ & $\begin{array}{l}\text { Share of riders who } \\
\text { finished the race } \\
(\%)(3 a) ; \\
\text { Coefficient of } \\
\text { variation of teams } \\
\text { finish rates }(3 \mathrm{a})\end{array}$ & 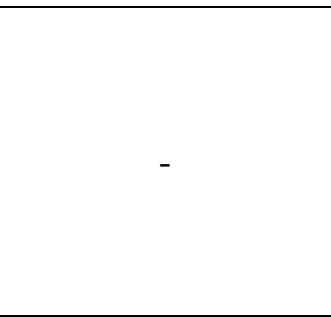 & $\begin{array}{l}\text { Share of finishers in } \\
\text { year } n \text { who had already } \\
\text { finished the race in } \\
\text { year n-1 (4a); } \\
\text { Correlation between } \\
\text { teams' finish rates in } \\
\text { years n and n-1 (4b) }\end{array}$ & 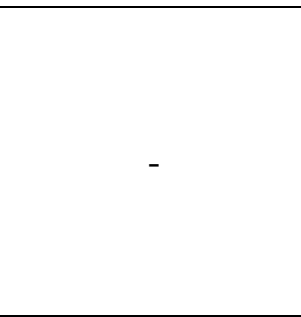 \\
\hline $\begin{array}{l}\text { Among } \\
\text { the top } 5 \\
\text { riders }\end{array}$ & - & $\begin{array}{c}\text { Best } 5 \text { riders' mean } \\
\text { delay (in } \% \text { of the } \\
\text { winner's time) (3b); } \\
\text { Coefficient of } \\
\text { variation of best } 5 \\
\text { riders' delays (3b) }\end{array}$ & j & $\begin{array}{l}\text { Correlation } \\
\text { between the best } 5 \\
\text { riders' delays (in } \\
\% \text { of the winner's } \\
\text { time) in years n } \\
\text { and n-1 }(4 \mathrm{c})^{*}\end{array}$ \\
\hline $\begin{array}{l}\text { Among } \\
\text { team } \\
\text { leaders }\end{array}$ & - & $\begin{array}{l}\text { Team leaders' mean } \\
\text { delay (in \% of the } \\
\text { winner's time) }(3 \mathrm{c}) \text {; } \\
\text { Coefficient of } \\
\text { variation of team } \\
\text { leaders' delays }(3 \mathrm{c})\end{array}$ & - & $\begin{array}{c}\text { Correlation } \\
\text { between team } \\
\text { leaders' delays (in } \\
\% \text { of the winner's } \\
\text { time) in years n } \\
\text { and n-1 (4d) }\end{array}$ \\
\hline
\end{tabular}

* Results are reported when computable on at least three riders

Because competitive balance is closely related to - and may be one of the determinants of - competitive intensity, some of the above indicators may be construed as indicators of both concepts. We take this fact into account when commenting on our results. 


\section{The Evolution of Competitive Balance in the Tour de France, 1947-2017}

\section{a. Static Competitive Balance Regarding Race Completion}

Since 1947 the number of riders has increased from 100 to close to 200 (Figure 2d) and more and more of them, from $50 \%$ in the late 1940s to $80 \%$ now, have been able to finish the race (Figure 3a). These changes may have induced more competitive intensity among riders but perhaps not necessarily more competitive balance among them, especially if those additional starters tend to perform less well than the others. Over the same period, teams' finish rates have become more similar to each other, i.e. more concentrated around their mean (Figure 3a), which indicates these rates now differ less from one team to another. Teams tend to finish the Tour with more and more similar shares of their riders left, which enables them to compete with each other on a more and more equal footing.

\section{b. Static Competitive Balance Regarding Final Time}

In the seventy Tours since 1947, the top five riders' mean delay has always been inferior to $0.35 \%$ of the winner's time (Figure $3 \mathrm{~b}$ ). In this sense, one might argue that the Tour includes a fair share of competitive balance - and perhaps also competitive intensity among top riders. In addition, the top five riders' mean delay slightly decreased from the $1950 \mathrm{~s}$ (when it was equivalent to $0.17 \%$ of the winner's time, on average) to the $2010 \mathrm{~s}(0.08$ $\%)$. This means that competitive balance and intensity have slightly improved over time. However, these improvements have not started or accelerated in the 1980s, which means they most likely are unrelated to the 1980s increase in the number of riders and teams and change in prize structure. At the same time, the dispersion (coefficient of variation) of the top five riders' delays has remained at a roughly constant level over the whole period (Figure 3b), which means that once the slight decrease in the top five riders' mean delay is taken into account, top riders' performances have remained at the same distance to each other.

By contrast, team leaders' mean delay has tended to increase since the late $1960 \mathrm{~s}$, from $0.3 \%$ of the winner's time in the second half of the 1960 s to $0.8 \%$ in the 2010 s (Figure $3 \mathrm{c}$ ). This is coherent with the fact that fewer team leaders than before are now able or willing to compete for the yellow jersey - many of them actually compete for other prizes, including stage wins. Team leaders' delays have also remained at a roughly constant level of dispersion over the whole period (around 1 or a bit below) (Figure 3c), which means team leaders have not become closer to each other.

Overall, these results reflect a slight improvement in static competitive balance among top riders since 1947, but deterioration in static competitive balance among team leaders since the late $1960 \mathrm{~s}$.

\section{c. Dynamic Competitive Balance Regarding Race Completion}

From the late 1940s, more and more riders participated in consecutive Tours. In addition, more and more of the riders who participated in consecutive Tours were also able to finish both races, from $40 \%$ in the late 1940 s to close to $50 \%$ in the 2010 s (Figure $4 \mathrm{a}$ ). Thus, it became easier to predict from one year to the next who the Tour finishers would be. More importantly, the correlation between teams' finish rates in consecutive years has mostly been positive (Figure $4 b$ ), which means that teams with a high finish rate in one year may be expected to also have a high finish rate the following year. However, since the 1950s this indicator has been on a decreasing trend, which means that teams' finish rates tend to be less predictable from one year to the next. 


\section{d. Dynamic Competitive Balance Regarding Final Time}

The correlation between the best five riders' delays and the same individual riders' delays in the previous year has mostly been strongly positive ( 0.51 on average) (Figure $4 \mathrm{c}$ ), which lends support to Andreff's claim (2015) that 'fans of the Tour de France are not often surprised by the name of the final winner of the race, usually not even by the three riders sharing the podium'. In addition, this correlation has not followed a clear trend over time (Figure 4c), which means that top riders' performances have remained roughly as easily predictable from one year to the next as before.

The correlation between team leaders' delays in consecutive years has also been mostly positive ( 0.39 on average) and it has not tended to decrease since the 1970 s (Figure 4d). In other terms, the performance of a team leader in a given year has remained as predictive of the performance of the leader of the same team the next year. This might not be as much of a problem as one might think, though: as Buzzacchi et al. (2003) have shown about the open soccer leagues of Europe, 'as long as the contest within each season is close (e.g. measured by standard deviation of win percent) then fans may be indifferent to dominance by a small number of teams over many seasons' (183).

Overall, these results reflect no clear improvement in dynamic competitive balance among top riders or among team leaders. Riders' performances have not become harder (or easier) to predict from one year to the next.

\section{Discussion}

What do these results tell us about the evolution of competitive balance in the Tour de France from 1947 to 2017? Teams have tended to finish the Tour with more similar shares of their riders left and teams' finish rates now tend to be less predictable from one year to the next than was the case before. In these respects, competitive balance has improved over time. More importantly, static competitive balance has improved among top riders, which means that top riders have tended to have more and more equal performances. Whatever the causes of this evolution, it is a major trend in Tour history. Static competitive balance among team leaders has deteriorated since the late 1960s, however. Finally, dynamic (year-to-year) competitive balance has not improved over time among top riders or among team leaders, which means riders' performances have remained relatively 'easy' to predict from one year to the next. For the public, however, getting to know the teams and the names, faces and voices of the few contenders who are most likely to perform and win in the coming years may be as much an advantage as a disadvantage. Overall, the main findings of our analyses are mixed: they combine improving competitive balance among top riders and deteriorating competitive balance among team leaders.

A common point of all these findings, however, is that none of the measurable evolutions of competitive balance dates back to - or has accelerated in - the 1980s. This suggests that variations in competitive balance did not play a major role in the increasing economic success of the Tour since the 1980s. There was no specific increase in competitive balance since the 1980s to begin with. These results fit well with other results according to which variations in the success of the Tour de France depend little on the cycling dimension of the show. Poll data concerning French people's reasons for being interested in the Tour stress the importance of landscapes relative to sport matters such as competitive balance. In 2018, among the $27 \%$ of adults in France who declared that they were interested in the Tour, the most common reasons for being interested were that 'the Tour is part of the French heritage' $(61 \%)$ and 'the beauty of landscapes crossed' (53\%), more than 'the sporting aspect of the competition' (31\%) and 'riders' efforts' (28\%) (BVA 2018). Similarly, from 1997 to 2010, Flemish televised cycling viewership has been shown to depend less on race 
developments such as competitive balance than on stage characteristics such as mountain stages and week-end stages (Van Reeth 2013).

In an event as complex as the Tour de France, competitive balance is likely difficult to manipulate. Perhaps one of the few ways to increase competitive balance among Tour team leaders would be to reduce the number of riders per team, which would both reduce and equalize resources available to team leaders (Van Reeth 2015c). Similarly, Buzzacchi et al. (2003) have shown that the closed leagues of North America (football, baseball, hockey) are much more balanced than the open leagues of Europe (soccer), in the sense that relatively more teams are likely to experience any given level of success in a given period of time. This is because of the greater extent of resource equalization measures in North America (draft rules, roster limits, salary caps, gate revenue sharing, collective merchandising, etc.).

If competitive balance is not what has driven more spectators to the Tour de France since the 1980s, then what is it? The most likely candidate is better-quality and longer television broadcasting. The proportion of the French population on the roadsides of the Tour decreased from the 1950s and 1960s to the 1970s and 1980s (Mignot 2016: 64), likely because the show has become even better on TV. The creation of additional private television channels in France and other European countries in the 1980s, including networks such as Eurosport, increased competition to get the Tour's TV broadcasting rights. This increased the amount of money channels were willing to spend to broadcast the Tour, just like similar developments increased television broadcasting funds for the 1984 Olympics in Los Angeles (Dyreson 2015). This development also incentivized the channels to improve broadcasting quality in order to increase their ratings and return on investment. On the Tour, motorbikes and helicopters now carried multiple cameras which filmed scenic landscapes as well as close-up images of live race interactions and spectators' reactions (Van Reeth 2015d). The increasing economic success of the Tour since the 1980s is likely not due to better races, but instead to better broadcasting of them. In this respect, it would be useful to complement our quantitative approach with more qualitative data sources detailing the improvements of television broadcasting of the Tour and their effects on spectators' willingness to watch this program. While the birth of the Tour de France in 1903 was related to the development of French sport newspapers and its interwar success was related to live radio broadcasting of the race finishes, its current economic success seems mostly due to better-quality television broadcasting worldwide - another development in the sphere of the media, rather than in the race itself. Improvements in broadcasting continue to this day, as exemplified by ultra-light on-board cameras that are fixed on some bicycles, enabling spectators to see and hear and experience the same things as champions do.

\section{References}

Andreff, Wladimir. 2015. "The Tour de France: A Success Story in Spite of Competition Imbalance and Doping.“ "In The Economics of Professional Road Cycling, edited by Daam Van Reeth and Daniel Joseph Larson, 234. New York: Springer.

Atkinson, Greg, Richard Davison, Asker Jeukendrup and Louis Passfield. 2003. "Science and cycling: current knowledge and future directions for research." Journal of sports sciences 21 (9): 767-787. doi: 10.1080/0264041031000102097

Bačík, Vladimír and Michal Klobučník. 2013. "History of Tour de France from the Geographical Point of View.“ Sport Science Review 22: 255-277. doi: 10.2478/ssr-2013-0013 
Buzzacchi, Luigi, Stefan Szymanski, and Tommaso M. Valletti. 2003. "Equality of opportunity and equality of outcome: Open leagues, closed leagues and competitive balance." Journal of Industry, Competition and Trade 3(3): 167-186.

BVA. 2018. Les préoccupations des Français. Vague 7. Les Français et le Tour de France. https://staticswww.bva-group.com/wp-content/uploads/2018/07/Sondage-BVA-pour-OrangeLes-Fran\%C3\%A7ais-et-le-Tour-de-France-Juillet-2018.pdf

Cabaud, Benjamin, Nicolas Scelles, Aurélien François and Stephen Morrow. 2015.

"Modeling Performances and Competitive Balance in Professional Road Cycling." In The Economics of Professional Road Cycling, edited by Daam Van Reeth and Daniel Joseph Larson, 257-283. New York: Springer.

Candelon, Bertrand and Arnaud Dupuy. 2015. "Hierarchical Organization and Performance Inequality: Evidence from Professional Cycling." International Economic Review 56 (4): 1207-1236. doi: 10.1111/iere.12135

Chany, Pierre and Thierry Cazeneuve. 2003. La Fabuleuse Histoire du Tour de France. Geneva: Minerva.

Dauncey, Hugh and Geoff Hare. 2003. The Tour de France, 1903-2003. A Century of Sporting Structures, Meanings and Values. London: Frank Cass.

Dejonghe, Trudo. 2015. "Sports, Economics of." In International Encyclopedia of the Social and Behavioral Sciences (Second Edition). Edited by Neil Smelser and Paul Baltes, 319. Amsterdam: Elsevier.

Dyreson, Mark. 2015. "Global Television and the Transformation of the Olympics: The 1984 Los Angeles Games." The International Journal of the History of Sport 32 (1): 172-184. doi: 10.1080/09523367.2014.983086.

Fink, Alexander and Daniel J. Smith. 2012. "Norms in Sports Contests: The Tour de France." Journal of Sport Management 26 (1): 43. doi: 10.1123/jsm.26.1.43

Gaboriau, Philippe. 2003. "The Tour de France and cycling's Belle Epoque." The International Journal of the History of Sport 20 (2): 57-78. doi: $10.1080 / 09523360412331305633$.

Humphreys, Brad R. and Nicholas M. Watanabe. 2012. "Competitive Balance." In The Oxford Handbook of Sports Economics: The Economics of Sports Volume 1, edited by Leo H. Kahane and Stephen Shmanske, 18-37. Oxford: Oxford University Press.

Ifop. 2014. Les Français et le Tour de France de cyclisme. https://www.ifop.com/wpcontent/uploads/2018/03/2723-1-study_file.pdf

Ifop. 2011. L'intérêt pour le Tour de France en Europe. Résultats détaillés. https://www.ifop.com/wp-content/uploads/2018/03/1559-1-study_file.pdf

Larson, Daniel J. and Joel G. Maxcy. 2014. "Uncertainty of outcome and radio policy in professional road cycling." Journal of Sport Management 28: 311-323. doi: 10.1123/jsm.2012-0295

Leeds, Michael A. and Peter von Allmen. 2016. The Economics of Sports, Fifth Edition. New York: Routledge.

McGann, Carol and Bill McGann. 2006. The Story of the Tour de France vol. 1. Indianapolis: Dog Ear Publishing. 
McGann, Carol and Bill McGann. 2008. The Story of the Tour de France vol. 2. Indianapolis: Dog Ear Publishing.

Mignot, Jean-François. 2014. Histoire du Tour de France. Paris: La Découverte.

Mignot, Jean-François. 2015a. "The History of Professional Road Cycling." In The Economics of Professional Road Cycling, edited by Daam Van Reeth and Daniel Joseph Larson, 7-31. New York: Springer.

Mignot, Jean-François. 2015b. "Strategic Behavior in Road Cycling Competitions." In The Economics of Professional Road Cycling, edited by Daam Van Reeth and Daniel Joseph Larson, 207-231. New York: Springer.

Mignot, Jean-François. 2016. "An Economic History of the Tour de France." In Sports Through the Lens of Economic History, edited by John K. Wilson and Richard Pomfret, 5570. Cheltenham: Edward Elgar.

Rottenberg, Simon. 1956. “The Baseball Players' Market.“ Journal of Political Economy 64: 242-258.

Scelles, Nicolas, Jean-François Mignot, Benjamin Cabaud and Aurélien François. 2017. "Temporary organizational forms and coopetition in cycling: What makes a breakaway successful in the Tour de France?" Team Performance Management: an International Journal. doi: 10.1108/TPM-03-2017-0012

Scelles, Nicolas, Christophe Durand, Liliane Bonnal, Daniel Goyeau and Wladimir Andreff. 2013. "Competitive balance versus competitive intensity before a match: is one of these two concepts more relevant in explaining attendance? The case of the French football Ligue 1 over the period 2008-2011." Applied Economics, 45, 4184-4192.

Szymanski, Stefan. 2006. "Uncertainty of outcome, competitive balance and the theory of team sports." In Handbook on the economics of sport, edited by Wladimir Andreff and Stefan Szymanski, 597-600. Cheltenham: Edward Elgar.

Vamplew, Wray. 2015. "In Praise of Numbers: Quantitative Sports History.“ The International Journal of the History of Sport 32 (15): 1835-1849. doi: 10.1080/09523367.2015.1106477.

Vandeweghe, Hans. 2015. "Doping in Cycling: Past and Present". In The Economics of Professional Road Cycling, edited by Daam Van Reeth and Daniel Joseph Larson, 285-311. New York: Springer.

Van Reeth, Daam. 2013. "TV demand for the Tour de France: the importance of stage characteristics versus outcome uncertainty, patriotism and doping." International Journal of Sport Finance 8 (1): 39-60.

Van Reeth, Daam. 2015a. "Globalization in Professional Road Cycling.“ In The Economics of Professional Road Cycling, edited by Daam Van Reeth and Daniel Joseph Larson, 165-205. New York: Springer.

Van Reeth, Daam. 2015b. "The Finances of Professional Cycling Teams." In The Economics of Professional Road Cycling, edited by Daam Van Reeth and Daniel Joseph Larson, 77. New York: Springer.

Van Reeth, Daam. 2015c. "The Future of Professional Road Cycling." In The Economics of Professional Road Cycling, edited by Daam Van Reeth and Daniel Joseph Larson, 313-341. New York: Springer. 
Van Reeth, Daam. 2015d. "TV Viewing of Road Cycling Races." In The Economics of Professional Road Cycling, edited by Daam Van Reeth and Daniel Joseph Larson, 99-128. New York: Springer.

Walter C. Neale, Walter, C. 1964. "The peculiar economics of professional sports." Quarterly Journal of Economics 78 (1): 1-14.

Wille, Fabien. 2003. "The Tour de France as an agent of change in media production." The International Journal of the History of Sport 20 (2): 128-146. doi: 10.1080/09523360412331305663. 
Figure 1. Tour de France revenues, 1950-2013 (in 2013 dollars)

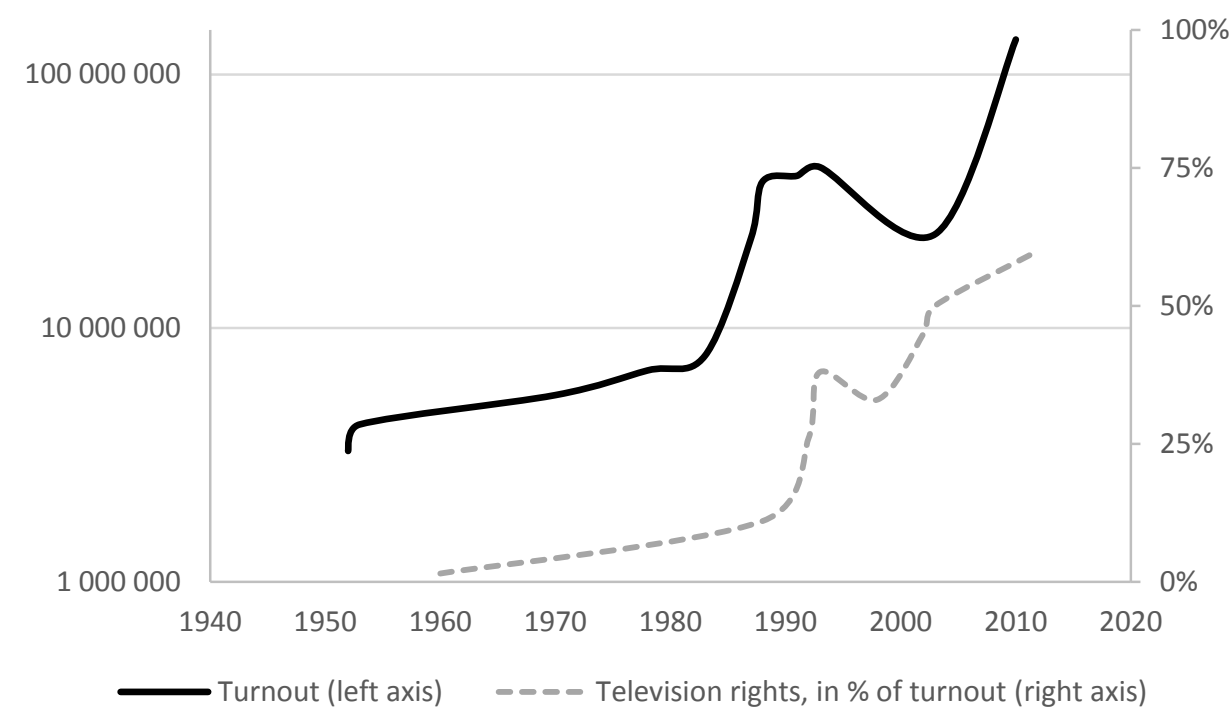

Source: Mignot 2016. 


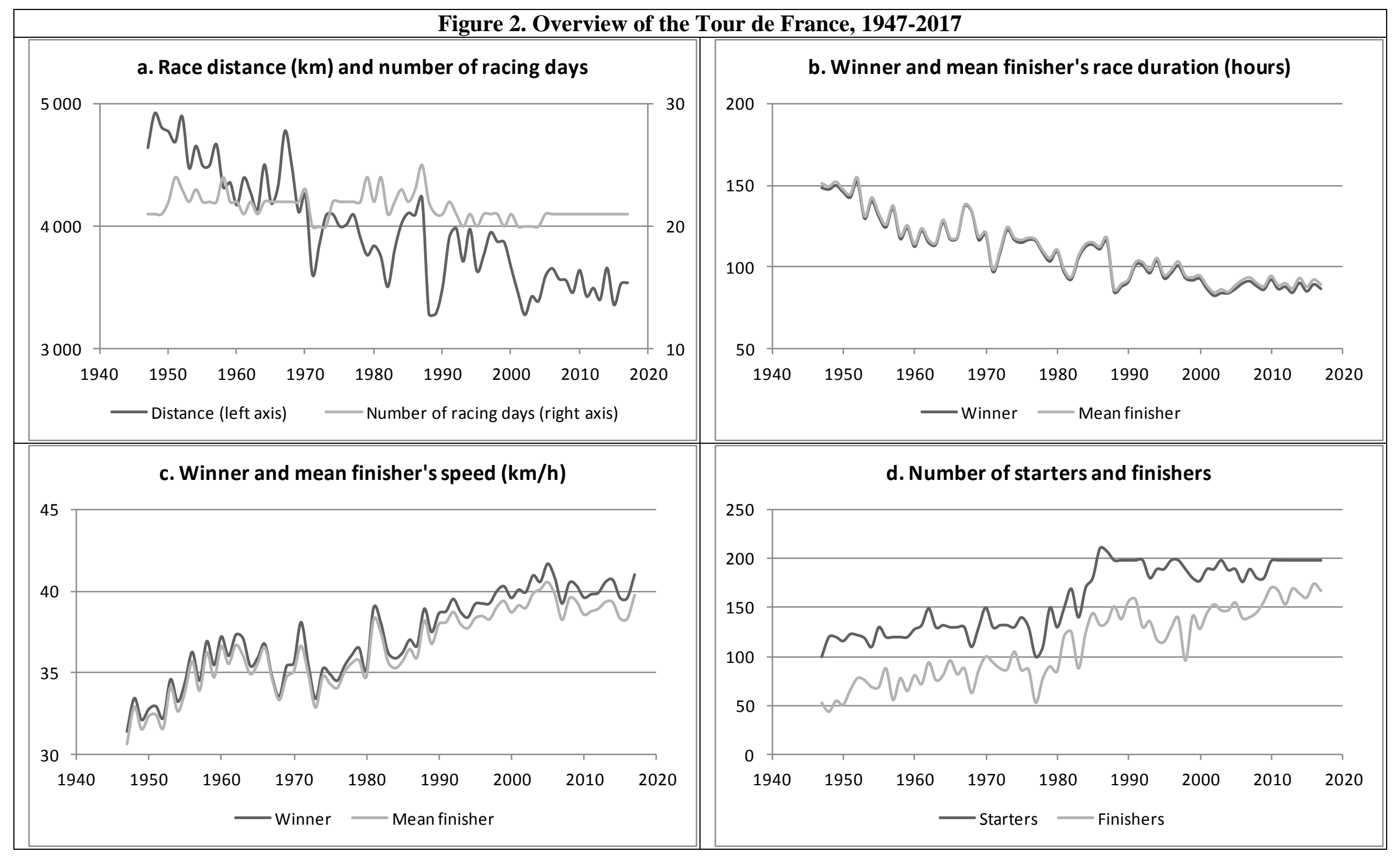




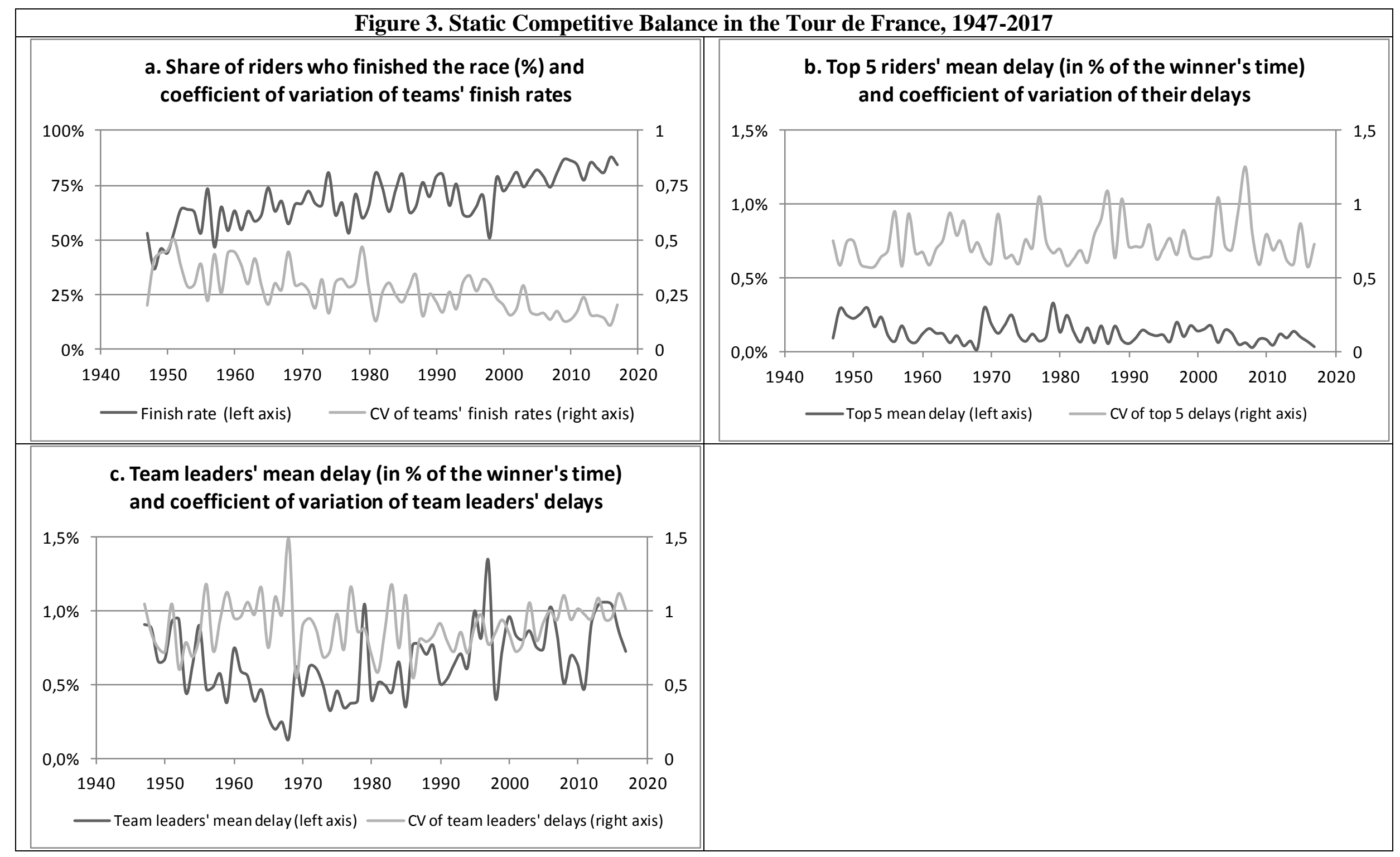


Figure 4. Dynamic Competitive Balance in the Tour de France, 1947-2017

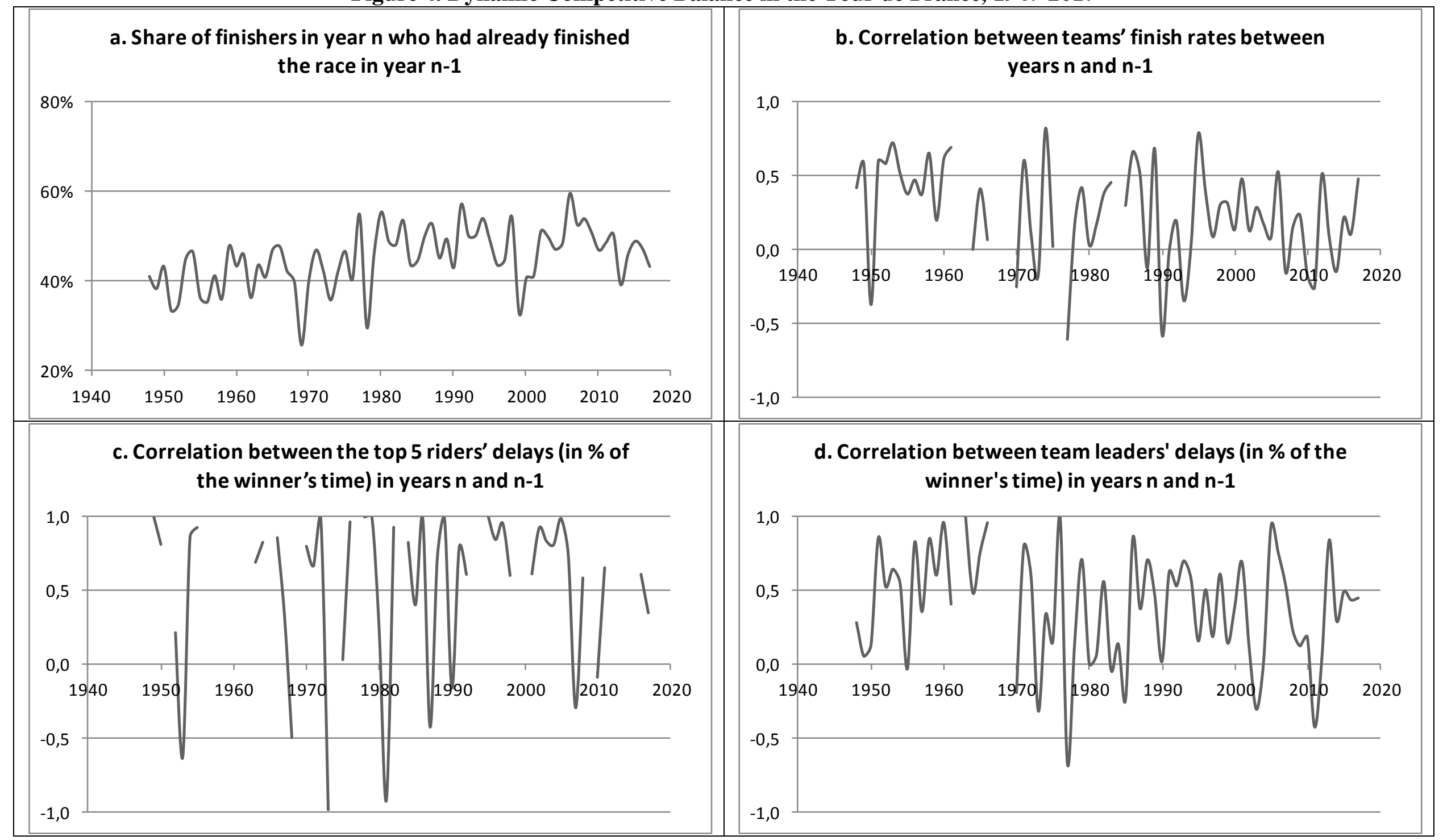


